\title{
The effect of structural abnormalities on dental substrates adhesion: A systematic literature review
}

\author{
Meriem Amine*, Sara Benfaida, Habiba Elfariati, Fatima-Zahra Mahdoud, Sarah Saif and Anas Bennani \\ Fixed Prosthesis Department, Faculty of Dentistry of Casablanca, University Hassan 2 of Casablanca, Morocco
}

\begin{abstract}
Introduction: During the odontogenesis, structure abnormalities could occur within dental hard tissues. These primary or aqcuired structural malformations bring major therapeutic challenges, notably while performing adhesive dentistry.

Aim: Through the present systematic review, we intent to assess the adhesive interface, between abnormal dental structure and restoration materials, in order to identify the techniques that can improve its quality.

Methods: The systematic search was undergone in three electronic databases : PubMed, ScienceDirect and Google Scholar, using the following key words: teeth abnormalities, Dental enamel, Enamel defect, fluorosis, amelogenesis imperfecta, Acid etching, Bonding, ultrastructure. A manual search was performed based on the electronic search bilbiography. Published articles, after 2000, were identified by reading titles and abstracts. Their critical analysis was done based on the reading grid (Audet N. Ledère H, Pédagogie médicale) and the literature analysis guide (approved by the Agence Nationale d'accréditation et d'évaluation en santé ANAES/HAS).

Results: Among the 400 articles initially found, 110 were selected and 31 english articles were retained, after full reading. Prospective studies and systematic reviews have been conducted on four structural anomalies : amelogenesis imperfecta, fluorosis, Molar Incisor Hypomineralization and dentinogenesis imperfecta.

Discussion: According to the found data, and in comparison with healthy dental tissues, lower adhesive bonding of filling materials have been noticed, on teeth with structural abnormalities. To overcome this problem, various techniques have been suggested, such as the deproteinization using the sodium hypochlorite solution, the micro abrasion, the prolonged etching, or the use of adhesion promoters.

Conclusion: The quality of adhesive bonding to enamel and dentine is decreased in case of sutructural abnormalities, which is a real clinical challenge in dental practice. Phosphoric acid etching, without prolonged application, is recommended for damaged teeth with amelogenesis imperfecta. In the case of fluorosis, micro abrasion treatment, as well as prolonged etching, have been proven useful to the bonding protocol.
\end{abstract}

More clinical trials with long term follow-up are required, in order to improve the adhesion quality in presence of the several structural abnormalities.

\section{Introduction}

Patients aesthetic needs have increased in the era of minimally invasive and conservative dentistry. Consequently, the bonding process has become an essential procedure in dental practice, and a main focus for constant materials evolution. Respecting healthy dental structure, the adhesive bonding principles are currently well known : with regard to the healthy enamel, we obtain the classic facies, enabling the resin macro mechanical anchoring. Concerning the dentin surface, the mechanism remains more complex because of its intrinsic humidity. The acid etching removes the main smear layer and deminerlises the dentinal tubules. The collagen network becomes exposed and forms the hybrid layer, after adhesive resin infiltration.

In the presence of dental structural abnormalities, the enamel and/ or the dentin composition and structure change. Thus, the bonding adhesive techniques become challenging. The literature reports a failure rate of $43 \%$ of the restorations designed on dental compromised structures.

In view of this significant low longevity, the issue that arises is: to what extent the compromised dental surface is able to provide a sufficient connection with the bonding materials (composites or ceramic).
The purpose of this article is to assess the adhesion quality on damaged structural teeth, and to identify the recommended techniques for their optimal bonding.

\section{Material and methods}

A literature computerized search was conducted in PubMed, Science Direct and Google Scholar, using the key words with the following boolean equations : bonding AND teeth abnormalities ; acid etching dental / method; dental enamel ultrastructure AND dental bonding ; enamel defect / dental bonding; amelogenesis imperfecta / therapy ; dental bonding / methods AND fluorosis ; dental bonding / methods AND amelogenesis imperfecta.

${ }^{\star}$ Correspondence to: Meriem AMINE, Associate Professor, Fixed Prosthesis Department, Faculty of Dentistry of Casablanca, University Hassan 2 of Casablanca, Morocco, Tel: 00212665012 021; E-mail: meriemamine@hotmail.com

Key words: teeth abnormalities, dental enamel, enamel defect, fluorosis, amelogenesis imperfecta, acid etching, bonding, ultrastructure

Received: March 06, 2019; Accepted: March 15, 2019; Published: March 18, 2019 
This work was limited to published articles after 2000 ; namely clinical studies, clinical trials and literature reviews. The case reports, experts opinion and studies with lack of methodology were excluded. A manual investigation was done using a bottom-up research, and based on the references previously identified in the bibliography.

Titles and abstracts reading followed by full reading did allow to retain the articles that meet the inclusion criteria cited above.

The articles critical analysis was undergone based on the reading grid (Audet N. Ledère H, Pédagogie médicale), and the literature analysis guide (approved by the Agence Nationale d'accréditation et d'évaluation en santé ANAES/HAS).

\section{Results}

Among the 400 collected articles in the literaure search, 110 were identified after title and abstract reading. The full reading has allowed us to retain 31 articles, that meet the above named inlcusion criteria (Figure 1).

The 31 retained references are anglophone, including prospective, retrospective and descriptive studies, randomized clinical trials, cohort studies, and literature reviews. All of them treating the adhesive bonding on four abnormalities : amelogenesis imperfecta (Table 1), fluorosis (Table 2), Molar Incisor Hypomineralisation (Table 3), and dentinogenesis imperfecta (Table 4).

\section{Discussion}

\section{Amelogenesis Imperfecta (AI)}

The amelogenesis imperfecta (AI) is an inherited disorder related to enamel formation. Four main types can be identified : hypoplastic, hypomature, hypomineralized, and hypomature or hypoplastic associated with taurodontism. The structure alterations found within this abnormality may modify the enamel and dentin adhesiveness values $[1,2]$.

The healthy enamel adhesiveness value is higher than the damaged enamel with an AI. The studies have shown that the three classic etching facies present on a healthy enamel are found within the hypomineralized and hypomature AI, even though these two are characterized with a defective mineralization. Consequently, their etching with $35 \%$ phosphoric acid is kept optimal.

Nevertheless, in the case of hypoplasia, the etching quality depends on the clinical form. The bonding remains suitable within pitted hypoplasia cases, but may be affected in other clinical forms (X-linked hypoplasia, smooth hypoplastic AI) [3-7].

The dentin adhesiveness value, in the case of $\mathrm{AI}$, is lower than a normal dentin. It may be due to the structure similarity between an affected dentin with $\mathrm{AI}$ and sclerotic dentin. This last one has a lower bondability than a healthy dentin [8-10]. However, the bonding strength to the damaged dentin remains significantly higher than the damaged enamel $[1,3]$.

In 2011, Pugach and co-workers have compared the adhesive systems effectiveness ; on damaged teeth with hypoplastic and hypomature AI. Higher adhesiveness values have been found with self-etching systems as compared to etch-and-rinse systems [11]. This can be explained by loosing the remaining enamel, leaving the dentin surface partly exposed by the etching, which allows the self-etching to be more efficient.

More than 400 articles after the computerized and manual search of the literature

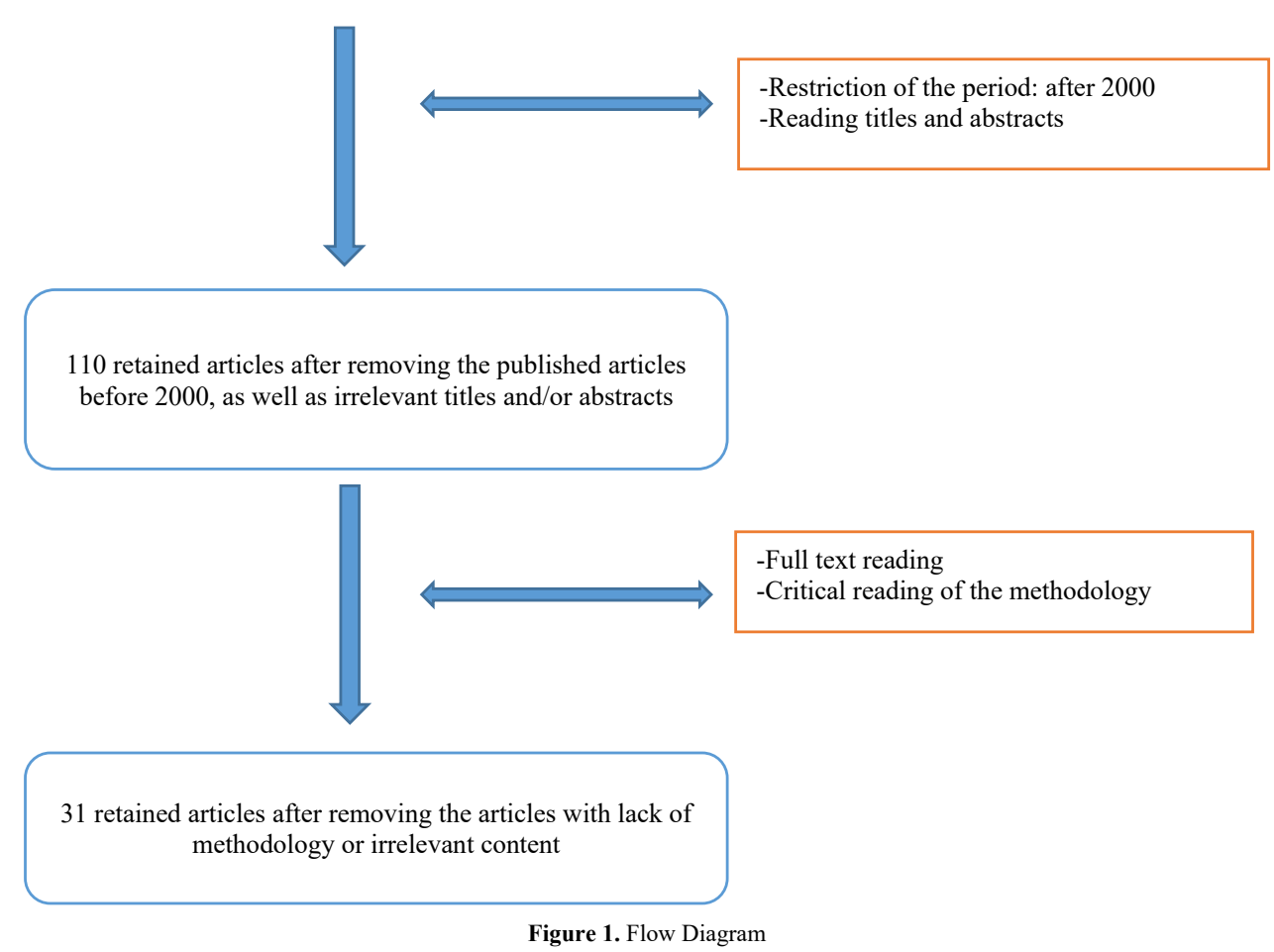

Figure 1. Flow Diagram 
Table 1. Adhesion to dental substrates affected by amelogenesis imperfecta (AI)

\begin{tabular}{|c|c|c|c|c|}
\hline Authors and years & Type of study & Objectives & Sample & Results \\
\hline $\begin{array}{l}\text { William } V \text { and } \\
\text { co-wokers [29]. }\end{array}$ & $\begin{array}{l}\text { Dexcriptive } \\
\text { study }\end{array}$ & $\begin{array}{l}\text { *To evaluate the adhesion to } \\
\text { hypomineralized enamel. }\end{array}$ & $\begin{array}{l}* 44 \text { normal teeth } \\
* 45 \text { teeth with hypomineralized } \\
\text { enamel. }\end{array}$ & $\begin{array}{l}\text { *The adhesion to affected enamel was significantly lower than the } \\
\text { adhesion to normal teeth. } \\
\text { *Penetration depth: } \\
\text { Deep for normal enamel } \\
\text { Shallow for affected enamel }\end{array}$ \\
\hline $\begin{array}{l}\text { Sanchez-Quevedo } \\
\text { and co-workers } \\
\text { [8]. }\end{array}$ & Descriptive study & $\begin{array}{l}\text { *To examine the dentin structure in } \\
\text { case of hypocalcified AI. }\end{array}$ & $\begin{array}{l}* 46 \text { fragments of damaged } \\
\text { permanent teeh with hypocalcified } \\
\text { AI. }\end{array}$ & $\begin{array}{l}\text { *The damaged teeth dentin has a peritubular dentin thickening and a } \\
\text { partial obliteration of the dentinal tubules. } \\
\text { *with a higher calcium content compared to healthy teeth. }\end{array}$ \\
\hline $\begin{array}{l}\text { Kim Seow and } \\
\text { co-workers }[4] \text {. }\end{array}$ & Descriptive study & $\begin{array}{l}\text { *To identify the surface type after } \\
\text { enamel acid-etching, on } 5 \text { clinical } \\
\text { types of AI, using the scanning } \\
\text { electron microscpe. }\end{array}$ & $\begin{array}{l}* 5 \text { premolars with } \mathrm{AI} \\
* 2 \text { normal premolars }\end{array}$ & $\begin{array}{l}\text { *A central dissolving of the enamel prisms has been observed among } \\
\text { cases with pitted hypoplasia (Etching pattern type 1) } \\
\text { *Eviction of the peripheral enamel prisms, recalling the type } \\
2 \text { hypoplasia linked to X predominates among females, type } 3 \\
\text { predominates among males. } \\
\text { *Hypomineralized AI: all the types exist equally. } \\
\text { *In case of smooth hypoplastic AI, there is no difference compared to } \\
\text { non-etched enamel. }\end{array}$ \\
\hline $\begin{array}{l}\text { Sanchez-Quevedo } \\
\text { and co-workers } \\
\text { [6]. }\end{array}$ & $\begin{array}{l}\text { Prospective } \\
\text { study }\end{array}$ & $\begin{array}{l}\text { *To examine the damaged enamel } \\
\text { structure with hypomineralized AI, } \\
\text { after } \mathbf{3 5 \%} \text { phosphoric acid etching, } \\
\text { for } 30 \text { seconds. }\end{array}$ & $\begin{array}{l}* 5 \text { fragments of permanent teeth } \\
\text { damaged with hypomineralized AI. }\end{array}$ & $\begin{array}{l}\text { *The etching patterns found are type } 1 \text { and } 2 \text {. Type } 3 \text { was not observed. } \\
\text { (refer to the post scriptum PS) } \\
\text { *No significant difference within calcium content, between the } \\
\text { damaged enamel with AI and healthy one, after } 35 \% \text { phosphoric acid } \\
\text { etching, for } 30 \text { seconds. }\end{array}$ \\
\hline $\begin{array}{l}\text { Pugach MK and } \\
\text { co-workers [11]. }\end{array}$ & $\begin{array}{l}\text { Prospective } \\
\text { study }\end{array}$ & $\begin{array}{l}\text { *To observe the healthy enamel } \\
\text { surface and the one damaged with AI } \\
\text { after etching } \\
\text { *To compare the adhesiveness values } \\
\text { between } 2 \text { different adhesive systems: } \\
\text { Self-etching and etch-and-rinse. }\end{array}$ & $\begin{array}{l}\text { *Mouse models with AI specific } \\
\text { mutations. } \\
\mathrm{N}=30 \text {. }\end{array}$ & $\begin{array}{l}{ }^{*} \text { The self-etching leads to significantly higher adhesiveness values } \\
\text { compared to etch-and-rinse, whether with damaged or healthy enamel. } \\
\text { This difference is statistically significant. }\end{array}$ \\
\hline $\begin{array}{l}\text { Yaman BC and } \\
\text { co-workers [12]. }\end{array}$ & $\begin{array}{l}\text { Prospective } \\
\text { study }\end{array}$ & $\begin{array}{l}\text { *To compare the adhesiveness values } \\
\text { between } 2 \text { components self-etching } \\
\text { and etch-and-rinse systems, within a } \\
\text { damaged enamel with AI. } \\
\text { *To analyze the etched enamel } \\
\text { surface with scanning electron } \\
\text { microscope. }\end{array}$ & $\begin{array}{l}\text { *16 damaged molars with } \\
\text { hypoplastic AI } \\
\text { *12 control molars. }\end{array}$ & $\begin{array}{l}\text { *The } 2 \text { components self-etching and etch-and-rinse systems, applied on } \\
\text { damaged teeth with hypoplastic AI, do not differ significantly. } \\
\text { *A significant difference among the adhesiveness values has been found } \\
\text { within the damaged enamel with hypoplastic AI and the healthy enamel. } \\
\text { *The application of phosphoric acid on damaged enamel with AI } \\
\text { creates superficial grooves and dimples with similar diameter of } \\
\text { the prism. Regarding the primer; a slightly etched surface with less } \\
\text { distinctive features have been observed. }\end{array}$ \\
\hline $\begin{array}{l}\text { Hirashi and co- } \\
\text { workers [9]. }\end{array}$ & $\begin{array}{l}\text { Prospective } \\
\text { study }\end{array}$ & $\begin{array}{l}\text { *To examine the etching time } \\
\text { impact on the adhesiveness value } \\
\text { within affected dentin with AI. }\end{array}$ & $\begin{array}{l}\text { *6 primary molars affected with AI. } \\
* 6 \text { healthy temporary molars. }\end{array}$ & $\begin{array}{l}\text { *The adhesiveness values to the dentin affected with AI are lower than } \\
\text { those among healthy teeth. } \\
\text { *There is no significant difference between } 15 \text { seconds and } 30 \text { seconds } \\
\text { etching within AI damaged dentin; the adhesiveness values remain the same. } \\
\text { *Prolonged etching time to } 30 \text { seconds has an opposite effect on the } \\
\text { healthy dentin adhesiveness value. }\end{array}$ \\
\hline $\begin{array}{l}\text { Poussette } \\
\text { Lundergren and } \\
\text { Dahllop. }\end{array}$ & $\begin{array}{l}\text { Retrospective } \\
\text { study }\end{array}$ & $\begin{array}{l}\text { *To compare the longevity of dental } \\
\text { restorations among patients with AI. }\end{array}$ & $\begin{array}{l}* 82 \text { patients, With } 326 \text { composite } \\
\text { restorations on damaged teeth with } \\
\text { AI and } 62 \text { restorations on normal } \\
\text { teeth. }\end{array}$ & $\begin{array}{l}* \text { The restorations longevity is significantly lower among the patients } \\
\text { with AI, because } 24.7 \% \pm 35.1 \text { of the AI group require replacing a } \\
\text { pre-existing filling, or a new one during the study, compared to } 9.23 \% \\
\pm 23.7 \text { of the control group. }\end{array}$ \\
\hline $\begin{array}{l}\text { Saroglu I and co- } \\
\text { workers [5]. }\end{array}$ & $\begin{array}{l}\text { Prospective } \\
\text { study }\end{array}$ & $\begin{array}{l}\text { *To assess the effect of NaOCL } \\
\text { on composite adhesion within teeth } \\
\text { affected by hypocacified AI after acid } \\
\text { conditioning. }\end{array}$ & $\begin{array}{l}\text { *7 temporary teeth affected by } \\
\text { hypocalcified AI and } 7 \text { healthy } \\
\text { control teeth. }\end{array}$ & $\begin{array}{l}\text { *A significant difference has been found between the adhesiveness } \\
\text { value to the enamel with hypocalcified AI (13.92 MPa) and the healthy } \\
\text { enamel }(27.77 \mathrm{MPa}) \text {. } \\
\text { *The adhesiveness value to the affected dentin }(10.08 \mathrm{MPa}) \text { is } \\
\text { significantly lower than the normal dentin }(18.52 \mathrm{MPa}) \text {. } \\
\text { *The deproteinization with NaOCL does not have a significant impact } \\
\text { on the tissue adhesion whether it is healthy or affected. }\end{array}$ \\
\hline $\begin{array}{l}\text { Faria-e-Silva and } \\
\text { co-workers [3]. }\end{array}$ & $\begin{array}{l}\text { Prospective } \\
\text { study }\end{array}$ & $\begin{array}{l}\text { *To evaluate the hardness and the } \\
\text { adhesion to the damage enamel and } \\
\text { dentin with hypocalcified AI. } \\
\text { *To evaluate the influence of } \\
\text { NaOCL on the adhesion. }\end{array}$ & $\begin{array}{l}* 5 \text { affected molars with } \\
\text { hypocalcified AI } \\
* 5 \text { healthy control molars. }\end{array}$ & $\begin{array}{l}\text { *The healthy enamel is harder than the one affected with hypocalcified } \\
\text { AI, however the hardness of the dentin remains the same. } \\
\text { *The affected teeth have lower adhesiveness values compared to the } \\
\text { healthy ones, whether within the enamel or the dentin. } \\
\text { *The dentin adhesiveness values are significantly higher than the } \\
\text { enamel within the affected teeth. } \\
\text { *1minute exposure to } 5 \% \text { NaOCL, before the adhesive proceudre, does } \\
\text { not have a significant impact on the adhesion. }\end{array}$ \\
\hline $\begin{array}{l}\text { Sonmez and co- } \\
\text { workers. }\end{array}$ & $\begin{array}{l}\text { Prospective } \\
\text { study }\end{array}$ & $\begin{array}{l}\text { *To identify the effect of the } \\
\text { deproteinization, after acid } \\
\text { conditioning, on the composite } \\
\text { success within teeth affected by } \\
\text { hypocalcified AI. }\end{array}$ & $\begin{array}{l}* 32 \text { permanent teeth of } 4 \text { children } \\
\text { affected by hypocalcified AI. }\end{array}$ & $\begin{array}{l}\text { *The deproteinization with } 5 \% \text { NaOCL for } 1 \text { minute after acid etching } \\
\text { has no significant impact on the composite restoration success. } \\
\text { *The composite restorations of affected teeth, with hypocalcified } \\
\text { AI, have been considered clinically successful on the long term ( } 36 \\
\text { months). }\end{array}$ \\
\hline $\begin{array}{l}\text { Pugach and co- } \\
\text { workers [14]. }\end{array}$ & $\begin{array}{l}\text { Prospective } \\
\text { study }\end{array}$ & $\begin{array}{l}\text { *To study the effect of the } \\
\text { deproteinization on the composite } \\
\text { adhesion, within teeth affected by AI, } \\
\text { using self-etching system by scaning } \\
\text { electron microscop. }\end{array}$ & *30 teeth affected by AI. & $\begin{array}{l}\text { *The deproteinization does not have a significant effect on self-etching } \\
\text { system adhesion to an affectd enamel with AI. } \\
\text { *The dentin adhesion of damaged teeth with AI does not differ } \\
\text { significantly from the control group. }\end{array}$ \\
\hline
\end{tabular}

PS: Patterns type of etching:

Type 1: Disappearance of central prisms with intact periphery

Type 2: Dissolution prisms and central prisms intact

Type 3: Enamel dissolution is independent of the prismatic structure 
Table 2. Adhesion to dental substrates affected by fluorosis

\begin{tabular}{|c|c|c|c|c|}
\hline $\begin{array}{l}\text { Authors and } \\
\text { Years }\end{array}$ & Type of study & Objectives & Sample & Results \\
\hline $\begin{array}{l}\text { Ateyah and } \\
\text { Akpata }[15]\end{array}$ & Prospective study & $\begin{array}{l}\text { *To study the impact of the fluorosis } \\
\text { severity and the etchnig time on the } \\
\text { composite adhesion to enamel. }\end{array}$ & $\begin{array}{l}* 170 \text { teeth } \\
(\mathrm{TF} \text { Index }=0,1-3,4-6)\end{array}$ & $\begin{array}{l}\text { *The fluorosis severity does not affect the composite adhesion to } \\
\text { enamel (TF Index }=0,1-3,4-6 \text { ) } \\
\text { *Prolonged etching, from } 60 \text { seconds to } 120 \text { seconds, improves } \\
\text { the adhesion. }\end{array}$ \\
\hline $\begin{array}{l}\text { Jayasooriya } \\
\text { and co-workers } \\
{[24] .}\end{array}$ & Prospective study & $\begin{array}{l}\text { *To assess the effectiveness of } 2 \\
\text { components self-etching system: } \\
\text {-regarding the non-etched fluorotic } \\
\text { enamel with prolonged priming } \\
\text {-regarding etched fluorotic enamel, } \\
\text { roughened by enamel preparation. }\end{array}$ & *30 teeth & $\begin{array}{l}\text { *The mechanical pretreatment of fluoritic enamel improve the } \\
\text { adhesiveness values of self-etching system. } \\
\text { *Prolonged priming does not have a significant effect on the } \\
\text { adhesion to fluorotic enamel. } \\
\text { *Type } 2 \text { structure predominates within etched fluorotic enamel, } \\
\text { while more superficial etched surface is obtained on the non- } \\
\text { etched enamel, even with a prolonged priming. }\end{array}$ \\
\hline $\begin{array}{l}\text { Ermis and } \\
\text { Gokay }[20] .\end{array}$ & Prospective study & $\begin{array}{l}\text { *To study the effect of fluorosis on the } \\
\text { dentin adhesion, using a self-etching } \\
\text { system. }\end{array}$ & $* 40$ teeth $(\mathrm{TF}$ Index $=3,4$ and 5$)$ & $\begin{array}{l}\text { *No significant difference on the adhesiveness value of the } \\
\text { fluorotic dentin. }\end{array}$ \\
\hline $\begin{array}{l}\text { Weerasinghe } \\
\text { and co-workers } \\
{[19] .}\end{array}$ & Prospective study & $\begin{array}{l}\text { *To assess the adhesion of } 2 \\
\text { components self-etching system on } \\
\text { fluorotic enamel. } \\
\text { *To study the influence of phosphoric } \\
\text { acid etching before self-etching } \\
\text { application on fluorotic enamel. }\end{array}$ & $\begin{array}{l}\text { *80 fluorotic teeth categorized according } \\
\text { to TF Index to } 4 \text { groups (TFI: } 0,1,3 \\
4-6,7-8)\end{array}$ & $\begin{array}{l}\text { *No significant difference regarding the adhesion to enamel } \\
\text { within different fluorosis degrees. } \\
\text { *The application of } 37 \% \text { phosphoric acid before self-etching } \\
\text { gives higher adhesiveness values, compared to self-etching. This } \\
\text { difference is significant within moderate to severe fluorotic teeth. }\end{array}$ \\
\hline $\begin{array}{l}\text { Ermis and co- } \\
\text { workers }[20] .\end{array}$ & Prospective study & $\begin{array}{l}\text { *To compare the effectiveness of } \\
\text { etch-and-rinse and self-etching on } \\
\text { fluorotic enamel. } \\
\text { *To evaluate the effect on adhesion of } \\
\text { the enamel prepared with diamond bur. }\end{array}$ & $\begin{array}{l}* 10 \text { fluorotic teeth }(\mathrm{TFI}=5) \text { and } 11 \text { teeth } \\
(\mathrm{TFI}=0)\end{array}$ & $\begin{array}{l}\text { *The etch-and-rinse system gives better adhesion than the } 2 \\
\text { components self-etching, whether on flurotoic or healthy enamel. } \\
\text { * Regarding the } 2 \text { adhesive systems, the fluorotic enamel has } \\
\text { better adhesiveness values when roughened and prepared with } \\
\text { diamond bur. }\end{array}$ \\
\hline $\begin{array}{l}\text { Waidysekera } \\
\text { and co-workers } \\
{[22] .}\end{array}$ & Prospective study & $\begin{array}{l}* \text { To evaluate the effectiveness of } 3 \\
\text { adhesive systems on the fluorotic } \\
\text { dentin: } \\
1 \text { component self-etching, } \\
2 \text { components self-etching } \\
\text { and etch-and-rinse. }\end{array}$ & $\begin{array}{l}\text { *48 fluorotic teeth with different degrees } \\
\text { of severity (TFI= } 1-3, \text { TFI }=4-6 \text { ) }\end{array}$ & $\begin{array}{l}\text { *The adhesiveness values to the healthy dentin are higher } \\
\text { compared to slightly fluorotic dentin, followed by moderate } \\
\text { fluorotic, which has the lower values. } \\
\text { *The } 2 \text { components self-etching provides the best adhesiveness } \\
\text { values, followed by etch-and-rinse, then } 1 \text { component self- } \\
\text { etching, for the different degrees of fluorosis. }\end{array}$ \\
\hline $\begin{array}{l}\text { Ertugrul and } \\
\text { co-workers } \\
{[17] .}\end{array}$ & Prospective study & $\begin{array}{l}\text { *To evaluate the effectiveness on } \\
\text { fluorotic enamel of the three adhesive } \\
\text { systems: etch-and-rinse, } 2 \text { components } \\
\text { self-etching and } 1 \text { component self- } \\
\text { etching. }\end{array}$ & *136 fluorotic teeth $(\mathrm{TFI}=4-6)$ & $\begin{array}{l}\text { *The adhesiveness values to fluorotic enamel are significantly } \\
\text { lower compared to healthy enamel. } \\
\text { *The etch-and-rinse system provides the best adhesiveness } \\
\text { values, whether the teeth are fluorotic or healthy. }\end{array}$ \\
\hline $\begin{array}{l}\text { Shida and co- } \\
\text { workers }[18]\end{array}$ & Propsective study & $\begin{array}{l}\text { *To evaluate the adhesion to fluorotic } \\
\text { enamel of } 2 \text { components self-etching } \\
\text { system. } \\
\text { *To measure the surface pH level in } \\
\text { order to assess the acid resistance. }\end{array}$ & *20 fluorotic teeth $(\mathrm{TFI}=1-3)$ & $\begin{array}{l}\text { *The adhesiveness values to fluorotic enamel are significantly } \\
\text { lower compared to healthy teeth. } \\
\text { *Statistical discrepancies have been found regarding the surface } \\
\text { pH levels, within fluorotic and non-fluorotic enamel, before and } \\
\text { after } 2 \text { components self-etching application. }\end{array}$ \\
\hline $\begin{array}{l}\text { Isci and co- } \\
\text { workers }[21]\end{array}$ & Prospective study & $\begin{array}{l}\text { *To compare the braces adhesiveness } \\
\text { values to fluorotic enamel, using two } \\
\text { systems: self-etching and etch-and- } \\
\text { rinse. }\end{array}$ & $\begin{array}{l}* 40 \text { slightly fluorotic teeth } \\
(\mathrm{TFI}=1-3)\end{array}$ & $\begin{array}{l}\text { *There is no significant difference with the adhesiveness values, } \\
\text { between fluorotic and non-fluorotic enamel, using etch-and-rinse } \\
\text { system. } \\
\text { *The self-etching system schows lower adhesiveness values to } \\
\text { fluorotic enamel. }\end{array}$ \\
\hline $\begin{array}{l}\text { Silva Benitez } \\
\text { and co-workers } \\
{[16] .}\end{array}$ & Prospective study & $\begin{array}{l}\text { *To study the effect of fluorosis on } \\
\text { the adhesion of orthodontic tubes and } \\
\text { identify the optimal surface treatment } \\
\text { to improve it. }\end{array}$ & *140 moderate to severe fluorotic molars. & $\begin{array}{l}\text { *Fluorotic teeth have lower adhesiveness values compared to } \\
\text { healthy ones. } \\
\text { *Prolonged etching, to } 150 \text { seconds of moderate fluorotic teeth, } \\
\text { provides better adhesiveness values. } \\
\text { *Micro abrasion procedure followed by } 15 \text { seconds normal } \\
\text { etching improves significantly the adhesion to severe fluorotic } \\
\text { teeth. }\end{array}$ \\
\hline
\end{tabular}

By contrast, Yaman and al, in 2014 didn't found any significant difference between the two adhesive systems [12].

The lack of a standardized protocol within the two studies (the use of the same adhesive system, the sample size...) precludes a definitive conclusion.

To ensure a better adhesion, the researchers have conducted their studies following different chemical pathways :

The effect of prolonged etching was assessed by Hirasihi and al in 2008. They have demonstrated that doubling the acid etching time, from 15 to 30 seconds, reverses the adhesion values within a healthy dentin. Yet, it has no significant impact on a damaged dentin with AI [9].
The enamel deproteinization with sodium hypochlorite solution was suggested as an adhesion optimization strategy, by extruding the organic elements in the enamel structure, before the acid etching. This pretreatment has shown promising results, as it doubled the enamel etched surface from $48.8 \%$ to $94.47 \%$, for Saroglu team in 2006 [5]. But, it has not been proven efficient among the adhesiveness values studies, neither before nor after the etching $[3,13,14]$.

The conflicting findings drive to more studies, using the same protocol, before adopting the deproteinization as a therapeutical approach in the clinical practice. 
Table 3. Adhesion to dental substrates with Molar Incisor Hypomineralization MIH

\begin{tabular}{|c|c|c|c|c|}
\hline $\begin{array}{l}\text { Authors and } \\
\text { years }\end{array}$ & Type of study & Objectives & Sample & Results \\
\hline $\begin{array}{l}\text { Lygidakis and } \\
\text { co-workers } \\
{[25] .}\end{array}$ & $\begin{array}{l}\text { Prospective } \\
\text { cohort study }\end{array}$ & $\begin{array}{l}\text { *To evaluate the } \\
\text { composite restorations } \\
\text { clinical performance of } \\
\text { teeth affected by MIH. }\end{array}$ & $\begin{array}{l}\text { *52 composite restorations } \\
\text { on } 52 \text { MIH molars. }\end{array}$ & $\begin{array}{l}\text { *Within } 48 \text { months, } 95 \% \text { of the restorations were available for assessment, they have shown : } \\
\text {-Excellent retention } \\
\text {-Absence of any hypersensitivity } \\
\text {-Absence of any apical pathology on X-Ray examination. }\end{array}$ \\
\hline $\begin{array}{l}\text { Jalevik and } \\
\text { co-workers } \\
{[28] .}\end{array}$ & $\begin{array}{l}\text { Descriptive } \\
\text { study }\end{array}$ & $\begin{array}{l}\text { *To study the } \\
\text { hypomineralized } \\
\text { enamel structure } \\
\text { with scanning electron } \\
\text { microscope. }\end{array}$ & *10 hypomineralized teeth. & $\begin{array}{l}\text { *The basic structure of healthy enamel, with prisms and inter-prismatic areas, has also been } \\
\text { found within hypomineralized enamel, except for the assembled hydroxyapatite crystal, which } \\
\text { is rather loose and less organized. } \\
\text { *The severe the hypomineralization, the more important the porosity, with large inter- } \\
\text { crystalline areas. }\end{array}$ \\
\hline $\begin{array}{l}\text { William and } \\
\text { co-workers } \\
{[29] .}\end{array}$ & $\begin{array}{l}\text { Prospective } \\
\text { study }\end{array}$ & $\begin{array}{l}\text { *To study the resin } \\
\text { composite adhesion } \\
\text { to hypomineralized } \\
\text { enamel, using } 2 \text { adhesive } \\
\text { systems: etch-and-rinse } \\
\text { and } 2 \text { components self- } \\
\text { etching. }\end{array}$ & *45 hypomineralized teeth. & $\begin{array}{l}\text { *The adhesion of hypomineralized enamel is significantly lower than the healthy one. } \\
\text { *Self-etching system provides the higher adhesiveness values to hypomineralized enamel, } \\
\text { compared to etch-and-rinse system, but this difference is not statistically significant. }\end{array}$ \\
\hline $\begin{array}{l}\text { Ghandi and } \\
\text { co-workers } \\
{[30] \text {. }}\end{array}$ & $\begin{array}{l}\text { Randomized } \\
\text { clinical trial }\end{array}$ & $\begin{array}{l}\text { *To study the effect of } \\
\text { deproteinization } \\
\text { of the MIH enamel on } \\
\text { sealants infiltration. }\end{array}$ & *31 teeth affected by MIH. & $\begin{array}{l}\text { *The surface quality, notably created tags, seems similar whether the enamel is pre-treated or } \\
\text { not with sodium hypochlorite. }\end{array}$ \\
\hline $\begin{array}{l}\text { Moosavi and } \\
\text { co-workers } \\
{[31]}\end{array}$ & $\begin{array}{l}\text { Prospective } \\
\text { study }\end{array}$ & $\begin{array}{l}\text { *To evaluate the } \\
\text { effect of different } \\
\text { surface treatments of } \\
\text { hypomineralized enamel, } \\
\text { with orthodontic braces. }\end{array}$ & *75 hypomineralized teeth. & $\begin{array}{l}\text { *The enamel pre-treatment with } 5 \% \mathrm{NaOCL} \text { does not have a significant effect on the micro- } \\
\text { leakage. } \\
\text { *The application of } 2 \% \text { sodium fluoride gel for } 4 \text { minutes, before acid etching, on the } \\
\text { hypomineralized enamel, decreases significantly the enamel-adhesive micro-leakage. }\end{array}$ \\
\hline $\begin{array}{l}\text { Mathu Muju } \\
\text { K Wright } \\
\text { JT and co- } \\
\text { workers }[34] .\end{array}$ & $\begin{array}{l}\text { Literature } \\
\text { review }\end{array}$ & $\begin{array}{l}\text { To analyze the diagnosis } \\
\text { and methods of treatment } \\
\text { of teeth affected by MIH }\end{array}$ & 20 papers $(2002-2013)$ & $\begin{array}{l}\text { *Etiology of MIH is still not kown } \\
\text { *Confusion between diagnosis with other enamel defects (amelogenesis imperfecta) }\end{array}$ \\
\hline $\begin{array}{l}\text { Lygidakis and } \\
\text { co-workers } \\
{[25] .}\end{array}$ & $\begin{array}{l}\text { Systematic } \\
\text { review }\end{array}$ & $\begin{array}{l}\text { Critical analysis of } \\
\text { different therapeutic } \\
\text { modalities proposed by } \\
\text { the authors }\end{array}$ & 14 papers $(2000-2010)$ & $\begin{array}{l}\text { *The information provided on treatment of MIH is limited and empirical } \\
* \text { The management of MIH pathology faces several problems including the quality of adhesion } \\
\text { and it depends on the severity of the form } \\
\text { *Long term clinical trials are needed to provide guidelines for treating MIH }\end{array}$ \\
\hline $\begin{array}{l}\text { Willmott and } \\
\text { co-workers } \\
\text { [7]. }\end{array}$ & $\begin{array}{l}\text { Literature } \\
\text { review }\end{array}$ & $\begin{array}{l}\text { To identify the diagnosis } \\
\text { demarch, management } \\
\text { of the difficulties and } \\
\text { methods of treatment }\end{array}$ & 54 papers $(1987-2003)$ & $\begin{array}{l}\text { *Therapeutic gradient concept } \\
\text { *The choice of adhesive materials is a challenge for the adhesion to affected teeth }\end{array}$ \\
\hline
\end{tabular}

Table 4. Adhesion to dental substrates affected by dentinogenesis imperfecta (DI)

\begin{tabular}{|l|l|l|l|l|}
\hline $\begin{array}{l}\text { Authors and } \\
\text { years }\end{array}$ & Type of study & Objectives & Sample & Results \\
\hline $\begin{array}{l}\text { Gallusi and } \\
\text { co-workers } \\
{[\mathbf{3 3}] .}\end{array}$ & $\begin{array}{l}\text { *To examine the } \\
\text { enamel and the dentin } \\
\text { structure. } \\
\text { *To evaluate the } \\
\text { adhesion effectiveness } \\
\text { study } \\
\text { by dentinogenesis } \\
\text { imperfecta. }\end{array}$ & $\begin{array}{l}* 4 \text { molars affected by } \\
\text { dentinogenesis imperfecta II. }\end{array}$ & $\begin{array}{l}\text { *The enamel structure and minerlization do not appear modified, even with the presence of } \\
\text { significantly altered dentin. } \\
\text { *The affected dentin by dentinogenesis imperfecta shows lack of usual organization, absence or } \\
\text { *Thing a completely different aspect from normal dentin. } \\
\text { dentin, shows differences between the two substrates. It was impossible to find a normal hybrid } \\
\text { layer even with high magnification. }\end{array}$ \\
\hline
\end{tabular}

\section{Fluorosis}

Dental fluorosis is a dental dysplasia due to a chronic ingestion of fluoride. It usually occurs on permanent teeth, and comes in the form of hypomineralization of the external enamel surface $[15,16]$. The management of these lesions takes place in the therapeutic gradient concept, from the less invasive techniques to the most invasive protocols. These last ones will be performed in moderate to severe cases, such as directe adhesive technique, or setting up a covering cosmetic element, namely a veneer or a ceramic crown. All these techniques will invovle a bonding procedure, where the adhesiveness value may be influenced by the presence of the abnormality.

The adhesion to the damaged enamel is lower than to the healthy one no matter how severe the fluorosis is [15-19]. The well-known performance of etch-and-rinse systems on normal enamel is also proven, regarding the fluorotic enamel, and remains significantly higher than the self-etching systems outcome [17,20,21].
The adhesion to flurotic dentin is under-investigated. In 2007, Waidyasekra's team has confirmed the low adhesion to the damaged dentin. It has also demonstrated, unlike the enamel, that the adhesiveness value is influenced by the severity of the fluorosis; the more severe the fluorosis, the lower the adhesiveness [22].

However, Ermis and co-workers, in 2003, have recorded that the difference between the healthy dentin adhesion and the damaged dentin adhesion is not significant, when it comes to the moderate forms. The adhesiveness values, on fluorotic dentin, obtained by the self-etching systems are higher than those given by the etch-and-rinse systems [23].

Two different approaches are used, in order to improve the adhesion to fluorotic damaged tooth :

Chemical approach : A marked adhesion improvement, to the moderate fluorotic enamel, has been demonstrated after increasing the 
etching time to 60 seconds, 90 seconds, and even 120 seconds [15,16]. To extend the primer application time is not a practicable treatment, as it doesn't have a significant impact on the fluorotic enamel adhesion [24]. The application of $37 \%$ phosphoric acid, before using self-etching systems, improves significantly the enamel adhesion.

Micro-abrasion mechanical approach : Ermis and co-workers have shown that the adhesion is considerably improved while using a rotating instrument, to eleminate the external part of the hypermineralized enamel, to a thikness of $300 \mu \mathrm{m}$. This finding is consistent with the studies of Jayasooriya and co-workers in 2002, and Silva and co-workers in 2013 [16,20,24].

\section{Molar Incisor Hypomineralization}

The Molar Incisor Hypomineralisation $(\mathrm{MIH})$ is a qualitative defect of the enamel. Classified into mild, moderate to severe, MIH can affect one to all of the permanent molars, which is usually associated with the hypomineralization of the incisors [7,25-27].

The literature on the adhesion of teeth with MIH is still limited, compared to the one related to AI. This is due to the lack of extracted teeth that are hypomineralized and appropriate for testing in the meantime.

In 2006, William's team has compared the adhesion of the healthy enamel with the hypomineralized one, using self-etching adhesive systems. They have found a lower adhesion within the damaged enamel, which has a porous structure with cracks, comparing to healthy enamel. The low adhesiveness is mainly related to the formation of resinous intratubular flanges. Moreover, the comparison between the various adhesive systems does not show any significant difference [28,29].

The enamel pretreatment with 5\% sodium hypochlorite has been suggested, in order to improve the adhesion and remove the yellow dicsoloration. Yet, its efficiency has not been shown. The quality surface within the pretreated enamel and the control enamel were identical. There is also evidence, as it would be for healthy enamel, that applying $2 \%$ sodium fluoride for 4 minutes before the etching, has an opposite effect on the adhesion, by increasing the microleakage of the enameladhesive interface [30,31].

Despite the low adhesiveness recorded by the researchers, Lygdiakis and co-workers, in 2003, estimate that the long term sustainability remains satisfactory, when it comes to first hypomineralized permanent molars [32].

\section{Dentinogenesis Imperfecta}

The dentinogenesis imperfecta is a genetic condition, characterized by hypomineralized and fragile dentin. It is a qualitative defect that can be accompanied with a quantitaive defect, related to the structure of the dentin-pulp complex.

There are several articles treating the phenotypic variability of the damaged dentin, but rare are those studying its adhesion.

The bonding on these teeth seems to be less efficient than the other abnormalities. The scanning electron microscope of damaged teeth with dentinogenesis imperfecta, in Gallusi and co-workers study in 2006, has shown an abnormal hybrid layer. This outcome confirms the low adhesion quality. However, the bonding is not conraindicated.

Further sudies are needed to meet an optimal and specific adhesion technique for this kind of teeth $[33,34]$.

\section{Conclusion}

The structure abnormalities interfere with the adhesive rehabilitation. The literature ressources concerning the adhesion to such substrates are limited.

The adhesiveness to damaged structure with $\mathrm{AI}$ is lower than the normal teeth. The use of $37 \%$ phosphoric acid remains the best method to surface treatment. The effect of its prolonged application is not proven yet. Self-etching systems performance, in comparison with etch-and-rinse systems, as well as the enamel deproteinization, require further studies, before being included in the therapeutic arsenal.

The adhesive interface quality is decreased within fluorotic enamel and fluorotic dentin. Bonding to fluorotic teeth is improved by the micro abrasion mechanical treatment ; enhancing the surface roughness, as well as the prolonged etching; using self-etching systems associated with $37 \%$ phosphoric acid, prior etching.

The literature on $\mathrm{MIH}$ is limited. Neither the $5 \%$ hypochlorite sodium pretreatment, nor the application of $2 \%$ fluoride sodium gel for 4 minutes before the etching, have imporved the low damaged teeth adhesion. Yet the long-term prognosis of these teeth restorations remains satisfactory.

The adhesiveness to damaged teeth with dentinogenesis imperfecta is low, as it is impossible to find a normal hybrid layer. Nevertheless, further studies are required to develop secific techniques, ensuring optimal adhesion to the altered dental surfaces.

\section{Conflict of interest}

The authors declare that there is no conflict of interest regarding the publication of this article.

\section{References}

1. Crawford PJ, Aldred M, Bloch-Zupan A (2007) Amelogenesis imperfecta. Orphanet J Rare Dis 2: 17. [Crossref]

2. Pousette Lundgren G, Dahllöf G (2014) Outcome of restorative treatment in young patients with amelogenesis imperfecta. a cross-sectional, retrospective study. J Dent 42: 1382-1389. [Crossref]

3. Faria-e-Silva AL, De Moraes RR, Menezes Mde S, Capanema RR, De Moura AS, et al. (2011) Hardness and microshear bond strength to enamel and dentin of permanent teeth with hypocalcified amelogenesis imperfecta. Int J Paediatr Dent 21: 314-320. [Crossref]

4. Seow WK, Amaratunge A (1998) The effects of acid-etching on enamel from different clinical variants of amelogenesis imperfecta: an SEM study. Pediatr Dent 20: 37-42. [Crossref]

5. SaroÄŸlu I, Aras S, OztaÅŸ D (2006) Effect of deproteinization on composite bond strength in hypocalcified amelogenesis imperfecta. Oral Dis 12: 305-308. [Crossref]

6. Sánchez-Quevedo C, Ceballos G, Rodríguez IA, García JM, Alaminos M (2006) Acid-etching effects in hypomineralized amelogenesis imperfecta. A microscopic and microanalytical study. Med Oral Patol Oral Cir Bucal 11: E40-43. [Crossref]

7. Willmott R, BRYAN AE, DUGGAL MS (2008) Molar incisor hypomineralization: a literature review

8. European Archives of Paediatric Dentistry 9: 172-179. [Crossref]

9. Sánchez-Quevedo MC, Ceballos G, García JM, Luna JD, Rodríguez IA, et al. (2004) Dentine structure and mineralization in hypocalcified amelogenesis imperfecta: a quantitative X-ray histochemical study. Oral Dis 10: 94-98. [Crossref]

10. Hiraishi N, Yiu CK, King NM (2008) Effect of acid etching time on bond strength of an etch-and-rinse adhesive to primary tooth dentine affected by amelogenesis imperfecta. Int J Paediatr Dent 18: 224-230. [Crossref]

11. Tay FR, Pashley DH (2004) Resin bonding to cervical sclerotic dentin: a review. J Dent 32: 173-196. [Crossref] 
12. Pugach MK, Ozer F, Li Y, Sheth K, Beasley R, et al. (2011) The use of mouse models to investigate shear bond strength in amelogenesis imperfecta. $J$ Dent Res 90: 13521357. [Crossref]

13. Yaman BC, Ozer F, Cabukusta CS, Eren MM, Koray F, et al. (2014) Microtensile bond strength to enamel affected by hypoplastic amelogenesis imperfecta. $J$ Adhes Dent 16 : 7-14. [Crossref]

14. Sönmez IS, Aras S, Tunç ES, Küçükeşmen C (2009) Clinical success of deproteinization in hypocalcified amelogenesis imperfecta. Quintessence Int 40: 113-118. [Crossref]

15. Pugach MK, Ozer F, Mulmadgi R, Li Y, Suggs C, et al. (2014) Shear bond strength of dentin and deproteinized enamel of amelogenesis imperfecta mouse incisors. Pediatr Dent 36: 130-136. [Crossref]

16. Ateyah N, Akpata E (2000) Factors affecting shear bond strength of composite resin to fluorosed human enamel. Oper Dent 25: 216-222. [Crossref]

17. Silva-Benítez EL, Zavala-Alonso V, Martinez-Castanon GA, Loyola-Rodriguez JP, Patiño-Marin N, et al. (2013) Shear bond strength evaluation of bonded molar tubes on fluorotic molars. Angle Orthod 83: 152-157. [Crossref]

18. Ertuğrul F, Türkün M, Türkün LS, Toman M, Cal E (2009) Bond strength of different dentin bonding systems to fluorotic enamel. J Adhes Dent 11: 299-303. [Crossref]

19. Shida K, Kitasako Y, Burrow MF, Tagami J (2009) Micro-shear bond strengths and etching efficacy of a two-step self-etching adhesive system to fluorosed and nonfluorosed enamel. Eur J Oral Sci 117: 182-186. [Crossref]

20. Weerasinghe DS, Nikaido T, Wettasinghe KA, Abayakoon JB, Tagami J (2005) Microshear bond strength and morphological analysis of a self-etching primer adhesive system to fluorosed enamel. J Dent 33: 419-426. [Crossref]

21. Ermis RB, De Munck J, Cardoso MV, Coutinho E, Van Landuyt KL, et al. (2007) Bonding to ground versus unground enamel in fluorosed teeth. Dent Mater 23: 12501255. [Crossref]

22. Isci D, Sahin Saglam AM, Alkis H, Elekdag-Turk S, Turk T (2011) Effects of fluorosis on the shear bond strength of orthodontic brackets bonded with a self-etching primer. Eur J Orthod 33: 161-166. [Crossref]

23. Waidyasekera PG, Nikaido T, Weerasinghe DD, Tagami J (2007) Bonding of acid-etch and self-etch adhesives to human fluorosed dentine. J Dent 35: 915-922. [Crossref]
24. Ermi $\AA \ddot{Y}$ RB, Gokay N (2003) Effect of fluorosis on dentine shear bond strength of a self-etching bonding system. J Oral Rehabil 30: 1090-1094. [Crossref]

25. Jayasooriyap, Wettasinghe K, Ogata M, Nikaido T, Tagami J (2002) Micro-tensile bond strength of a self-etching primer bonding system to fluorosed enamel. Int Chin J Dent 2: 107-115.

26. Lygidakis NA (2010) Treatment modalities in children with teeth affected by molarincisor enamel hypomineralisation (MIH): A systematic review. Eur Arch Paediatr Dent 11: 65-74. [Crossref]

27. Fayle SA (2003) Molar incisor hypomineralisation: restorative management. Eur $J$ Paediatr Dent 4: 121-126. [Crossref]

28. Weerheijm KL, Jälevik B, Alaluusua S (2001) Molar-incisor hypomineralisation. Caries Res 35: 390-391. [Crossref]

29. Jälevik B, Dietz W, Norén JG (2005) Scanning electron micrograph analysis of hypomineralized enamel in permanent first molars. Int J Paediatr Dent 15: 233-240. [Crossref]

30. William V, Burrow MF, Palamara JE, Messer LB (2006) Microshear bond strength of resin composite to teeth affected by molar hypomineralization using 2 adhesive systems. Pediatr Dent 28: 233-241. [Crossref]

31. Gandhi S, Crawford P, Shellis P (2012) The use of a 'bleach-etch-seal' deproteinization technique on MIH affected enamel. Int J Paediatr Dent 22: 427-434. [Crossref]

32. Moosavi H, Ahrari F, Mohamadipour H (2013) The effect of different surface treatments of demineralised enamel on microleakage under metal orthodontic brackets. Prog Orthod 14: 2196-1042. [Crossref]

33. Lygidakis NA, Chaliasou A, Siounas G (2003) Evaluation of composite restorations in hypomineralised permanent molars: a four-year clinical study. Eur J Paediatr Dent 4: 143-148. [Crossref]

34. Gallusi G, Libonati A, Campanella V (2006) SEM-morphology in dentinogenesis imperfecta type II: microscopic anatomy and efficacy of a dentine bonding system. Eur J Paediatr Dent 7: 9-17. [Crossref]

35. Mathu-Muju K, Wright JT (2006) Diagnosis and treatment of molar incisor hypomineralization. Compend Contin Educ Dent 27: 604-610. [Crossref]

Copyright: $(02019$ Amine M. This is an open-access article distributed under the terms of the Creative Commons Attribution License, which permits unrestricted use, distribution, and reproduction in any medium, provided the original author and source are credited. 